\title{
IMAGE MEDIA AND THE RESULTS OF LEARNING OUTCOMES OF KONTRASTIVE KULTURKUNDE COURSES OF THE STUDENTS OF GERMAN LANGUAGE EDUCATION STUDY PROGRAM, FKIP PATTIMURA UNIVERSITY, AMBON
}

\author{
Tamaela Ida Costansa \\ idatamaela@yahoo.com \\ and \\ Melanius Sarbunan \\ German Language Department, Pattimura University, Ambon - Indonesia
}

\begin{abstract}
The purpose of this study is to determine the influence of the use of image media on the learning outcomes of students of the German Language Education Study Program in Kontrastive Kulturkunde courses that use image media and those that do not use images. The use of image media applied in this study follows what Macaire and Hosch (2004: 67) have suggested about the function of images, that images can reactivate students' initial knowledge (Vorwissen der Schülerinnen und Schüler), show similarities/authenticity (Authentizität) and indicate actual situations (Aktualität), a communicative perspective image of an object and a representative image, which is a visual that depicts the state of nature and people's lives. (Perspektive und Repräsentativität) and which have similarities or differ with their own culture (Nähe oder Ferne zur eigenen Kultur). This research was motivated by the low learning outcomes of students in Kontrastive Kulturkunde courses. The type of this research used is experiment with one group pretest - posttest design with t-test analysis technique with significance level $\alpha=0.05$. Testing the effectiveness of this study is with the use of image media. The target of this study was 20 students of semester 4, German Language Education Study Program FKIP Pattimura University Ambon in Kontrastive Kulturkunde courses. The result of the calculation appears that, tcount $>$ ttable $=1,729$ which is $11,103>1,729$. Based on the results of the calculation it can be said that, there is a noticeable difference between the value after and before the application of the image media.
\end{abstract}

Key Words : Image Mediar, Results of Learning, Kontrastive Kulturkunde

\section{Introduction}

Cross-Cultural Teaching (Kontrastive Kulturkunde) is often regarded as boring memorization teaching by learners. His teaching is considered to be oriented towards cognitive knowledge (kognitive Orientierung), that the themes discussed include history, politics, geography, literature and other themes that are nothing more than events that must be remembered and then answered again when answering exam questions. This kind of learning process has neglected the role of learners who are not given the opportunity to see their relevance to their present 
and future lives. Whereas in this era of globalization, students must be encouraged to learn critical thinking and more importantly so that students can be given understanding to learn to understand and accept the way of intercultural life. The purpose of this, is that when learners enter a new world with a different culture, they no longer awkwardly face it.

Indonesia, which is known for its cultural diversity, is very important to instill awareness of cultural diversity to students. With cultured awareness will make learners can understand more deeply about themselves. This allows for the establishment of meaningful relationships with other cultured people (Gebhard 2006: 123). Furthermore, what needs to be a concern in this teaching is a number of Kontrastive Kulturkunde subject matter that is still difficult for students to understand and teachers are difficult to explain. Such difficulties occur because of abstract, complicated and foreign material to explain caused by different cultural settings. For example, in explaining the daily culture in Germany (Alltagskultur), teachers should be able to address the condition by using image media so that students can see directly the topic being discussed. It is hoped that the use of image media can be used as a tool to introduce German culture. This strategy will make learning interesting and will make it easier for students to understand and recognize German culture in real time, especially for students who do not know the target culture (Germany) at all. Thus, it will activate the learner's interest in the subject he is studying and have the opportunity to creativity and develop their potential through activities directly in the surrounding environment.

\section{The Research method}

The research design, that be used in this study is one group pretest - posttest design . Testing the effectiveness of this study is with the use of image media. The target of this study is 20 students of semester 4, German Language Education Study Program FKIP Unpatii Ambon in Kontrastive Kulturkunde courses, namely one group pretest - post test design, with t-test analysis techniques. The collected learning data is analyzed statistically. The analysis was conducted by comparing the results of the Kontrastive Kulturkunde comprehension test, using image media in Kontrastive Kulturkunde courses. In this study only used one class of research, without comparison class. The average different test of the results of learning the understanding of Kontrastive Kulturkunde was conducted with a t-test, with a significance level of $\alpha=0.05$.

\section{The Learning Outcomes}

According to Bloom in Thobroni (2011: 23), learning outcomes include cognitive, affective and psychomotor abilities. It is said that cognitive domains include: a. knowledge; b. comprehension (understanding, explaining, summarizing, examples); c. application(apply); d. analysis (deciphering, determining relationships); e. synthesis (organizing, planning, forming new buildings); $\mathrm{f}$. evaluating. The next domain is to include an Affective domain:

According to Hamzah (2011: 190) assessment of student learning outcomes is an obligation of a teacher and is absolutely done. Furthermore, in the opinion of W. J. Kripsin and Feldhausen in Hamzah (2011: 190) evaluation is the only way to 
determine the accuracy of learning and success. Thus effective learning indicators can be known from the hasi good student learning.

Supriyono (2009: 5-6) suggests that the results of learning are patterns of deeds, values, understanding, attitudes, appreciation and skills. Then refer to Gagne's thoughts in Thobroni (2011: 22-23) the learning outcomes are as follows: a) Verbal information, i.e. the ability to express knowledge in the form of language, both oral and written. Ability to respond specifically to specific stimuli. These capabilities do not require symbol manipulation, problem solving, or rule enforcement; b) Intellectual skills, namely the ability to present concepts and symbols. Intellectual skills consist of the ability to categorize, analytical-synthetic ability of concept facts, and develop scientific principles. Intellectual skills are the ability to perform cognitive activities are typical; c) Cognitive strategy, namely the ability to channel and direct cognitive activities. These capabilities include the use of concepts and rules in solving problems; d) Motor skills, namely the ability to perform a series of physical movements in affairs and coordination so that the automaticity of physical motion is realized; (e) Attitude is the ability to accept or reject an object based on the assessment of the object. Attitude in the form of the ability to internalize and externalize values. Attitude is the ability to make values as a standard of behavior.

\section{Image Media}

According to Sadiman (2009: 6) the word media comes from Latin and is the plural of the word medium which literally means intermediary or introduction. Munadi (2008: 2) suggests that the use of media or tools is very helpful for learning process activities both inside and outside the classroom, especially helping to improve students' learning achievements. But in its implementation not many teachers use it, even the use of monotonous lecture methods is still quite popular among teachers in the learning process. Arif Sadiman in Munadi (2008:9) said that the media is software or emblems that contain messages or information presented with images or photos.

Sadiman (2009: 29) suggests images are the most commonly used medium. $\mathrm{He}$ is a common language, which can be understood and enjoyed everywhere. Hence the Chinese proverb says that a picture speaks more than a thousand words. The advantages of image media according to Sadiman are (a) concrete in nature, meaning that the image is more realistic and shows the subject matter compared to verbal media alone; (b) can overcome space and time constraints. Not all objects, objects or events can be brought to class, and not always can children be brought to those objects; (c) be able to overcome the limitations of our observations; (d) can clarify a problem in any field; (e) the price is cheap and easy to get and use.

Furthermore, the Domonique (2004: 8) argues that: Bilder gelten allgemein als leicht verständliche Mittel der Kommunikation, der Verständigung. Man meint, daß sie einfacher als fremdsprachliche Texte zu verstehen seien. Deshalb arbeiten viele Fremdsprachenlehrer und-lehrerinnen in ihrem Unterricht mit Abbildungen aus Lehrwerken, Bildbänden oder Illustrieren, mit Comics oder auch mit Karikaturen. 
The description above explains that images are tools that can facilitate or facilitate communication and are considered with images of people easier or quickly understand the topic they are studying. Therefore, foreign language teachers in the teaching and learning process are expected to use media such as illustrations such as comics or caricatures. Then he said that, like illustrations, like comics or caricatures, ein Bild spiegelt eine Welt, eine Kultur wider, und zwar des Landes, in dem das Bild entstanden ist. Das Bild gibt eine Information zu einem bestimmten Thema, es vermittelt einen Eindruck von einem Auschnitt aus der Kultur.

The image reflects the world, the culture, the country in which it was created. Images provide information about a particular topic, giving the impression of part of the culture. Regional information through images reflects various aspects of a country.

\section{Collagen erstellen}

According to Macaire \& Hosch (2004: 133) Collagen ist vor allem landeskundlich interessant: Die Studenten können das Thema des Bildes kreativ neu gestalten. Die Themenpalatte reicht von einfachen Beispielen - etwa Essen, Wohnen, Kleidung - über die Darstellung der eigenen Schule, Familie, Umwelt bis hin zu interkulturellen Fragestellungen ... wie verhält man sich in einem Cafe, bei einer Einladung? Die Schülerinnen und Schüler sammeln selbst Bild und auch Textmaterial und kleben es auf ein großes Stück Papier bzw. Pappe. Die Auswahl sollte den Schülern selbst überlassen bleiben. That means, the use of images in cultural teaching will be interesting if the media used is collagen that is images.

Through images, students can creatively follow new themes, for example about eating, shelter, and clothing. Then also about education, family and environment and how people fulfill an invitation in a Cafe. Then the cross-cultural materials or themes collected by the students can be affixed to large pieces of paper.

\section{Kontrastive Kulturkunde}

According to Sanga F. since 1957 through the book Linguistics Across Cultures, Lado has suggested making intercultural comparisons. In the book Lado uses a contrastive approach to compare cultures. According to him, people will not be able to learn a language without knowing its culture. People will be able to compare two different cultures if they already know the two cultures well.

According to Moeliono contrastive is interpreted as a difference or contradiction between two things. In Duden Richtiges und gutes Deutsch through a PC Bibliothek Langenscheidt interprets kontrast as der Gegensatz, das Unterschied; or vergleichend, gegenüberstellend which means comparison or difference. Furthermore Kulturkunde consists of two words, namely Kultur "Culture" and Kunde namely: verwendet, um eine Wissenschaft oder ein Schulfach zu bezeichnen. It means that it is used to show knowledge that is usually used in a subject.

So Kulturkunde means knowledge of culture. Cross cultural, according to Kramsch (2000: 81) was The term cross cultural or intercultural usually refers to the meeting of two cultures or two languages. In foreign languages teaching a cross cultural approach seeks ways to understand the other. The term intercultural may also refer to communication between people from different ethnic, social, gendered 
cultures. According to Zadeh: Landeskunde's learned purpose is "Die Ziele sind: Verstehen von fremdkulturellem Verhalten; Reflektion von eigenem Verhalten in anderen Kulturen; Erkennen kulturspezifischer Muster der Kommunikation; Analyse von fremden und bekannten Werten und Normen, Effizientes Handeln in anderen Kulturen, Herstellung von Vertrauen und Kooperation in internationalen Kontakten“. Sapir in Risager suggests that „language does not exist apart from culture, language is closely linked to culture.

\section{The Result of the Research}

The data described is the data of learning results after and before the application of Image Media. The average different test of Landeskunde's comprehension learning results is done by t-test, with the significance level $\alpha=0.05$ are as follows:

Test table the average difference of test results conducted with t test.

\begin{tabular}{|c|c|c|c|c|}
\hline $\begin{array}{c}\text { Respondent } \\
\text { number }\end{array}$ & $\begin{array}{l}\text { Pretest Score } \\
=X_{1}\end{array}$ & $\begin{array}{c}\text { Posttest Score } \\
=\mathbf{X}_{2}\end{array}$ & $D=X_{2}-X_{1}$ & $\mathbf{D}^{2}$ \\
\hline 1 & 50 & 70 & 20 & 400 \\
\hline 2 & 50 & 70 & 20 & 400 \\
\hline 3 & 60 & 70 & 10 & 100 \\
\hline 4 & 70 & 80 & 10 & 100 \\
\hline 5 & 40 & 70 & 30 & 900 \\
\hline 6 & 40 & 70 & 30 & 900 \\
\hline 7 & 60 & 80 & 20 & 400 \\
\hline 8 & 50 & 80 & 30 & 900 \\
\hline 9 & 60 & 80 & 20 & 400 \\
\hline 10 & 40 & 60 & 20 & 400 \\
\hline 11 & 50 & 60 & 10 & 100 \\
\hline 12 & 50 & 80 & 30 & 900 \\
\hline 13 & 70 & 80 & 10 & 100 \\
\hline 14 & 40 & 60 & 20 & 400 \\
\hline 15 & 60 & 70 & 10 & 100 \\
\hline 16 & 60 & 70 & 10 & 100 \\
\hline 17 & 40 & 60 & 20 & 400 \\
\hline 18 & 70 & 80 & 10 & 100 \\
\hline 19 & 60 & 80 & 20 & 400 \\
\hline 20 & 50 & 70 & 20 & 400 \\
\hline Total & 1070 & 1440 & 370 & 7900 \\
\hline
\end{tabular}

Where:

$$
S d^{2}=\frac{N \sum D^{2}-\left(\sum D\right)^{2}}{N(N-1)}
$$




$$
\begin{gathered}
S d=\sqrt{S d^{2}} \\
S d^{2}=\frac{20 x 7900-370^{2}}{20(20-1)}=\frac{158000-136900}{380}=\frac{21100}{380}=55,52632 \\
S d=\sqrt{55,52632}=7,4516 \\
t_{\text {count }}=\frac{370 / 20}{7,4516 \sqrt{20}}=\frac{18,5}{1,66623}=11,103
\end{gathered}
$$

Degrees free $(\mathrm{db})=\mathrm{N}-1=20-1=19, \alpha=0,05$, so $t_{\text {table }}=1,729$

From the calculation results above it appears that, $t_{\text {count }}>t_{\text {table }}=1,729$ that is $11,103>1,729$ then there is a noticeable difference between the after and before values which means reject $\mathrm{H} 0$.

\section{Discussion}

To teach students so that they can achieve their learning goals optimally, learning media facilities are required. The use of image media applied in this study is based on the function of images presented by Macaire and Hosch (2004: 67) which is an image for the teaching of Kontrastive Kulturkunde, (spezifische (landeskundliche) Kriterien), with the criteria of images, images that can reactivate the initial knowledge of students (Vorwissen der Schülerinnen und Schüler), authentic images (Authentizität) and actual images (Aktualität), images that are perspective and representative (Perspektive und Repräsentativität) and which have similarities or differ with their own culture (Nähe oder Ferne zur eigenen Kultur?).

Based on the explanation above, it can be said that the use of image media is very important because it can be used to analyze, interpret, comment and compare things seen from a particular image orally or in writing about the cultural material that students will learn. With images media, students' learning motivation can be improved and furthermore the images can make students passionate to learn. Through images students can freely ask questions or explain the images they see. Students are also encouraged to think analytically about what they see. Thus, through the medium of images, students' language skills can be improved, so that they have the courage to express opinions that can make their cultural knowledge develop.

The use of image media in this paper can also provide an overview and information about abstract things for students in the teaching of Kontrastive Kulturkunde. There is a Chinese proverb in Sadiman (2009: 29) said that a picture speaks more than a thousand words, because of its concrete nature, it can overcome the boundaries of space and time, can overcome the limitations of our observations, can clarify a problem. In addition, through the initial knowledge drawings students can be reactivated and students can describe the actual situation of objects.

\section{Conclusion}

Based on the discussion of the results of this study, it can be concluded that there are differences in test results through $t_{\text {count }} 11,103>1,729 t_{\text {table }}$ after and before the application of image media. Furthermore, in relation to efforts to improve 
the quality of learning, it is necessary to pursue a variety of interesting learning methods and techniques to improve the learning outcomes of learners. For the perfection of this research, it is necessary to hold further research with samples and larger groups by paying attention to other factors that contribute to the quality of learning.

\section{Bibliography}

Gebhard Jerry, G. 2006. Teaching English as a Foreign or Second language. Second Edition (USA : The University of Michigan Press.

Kramsch Claire, 2000. Language and Culture. Oxford : Oxford University Press Macaire Dominique dan Hosh Wolfram. 2004. Bilder in der landeskunde. Fernstudieneinheit 11. Berlin : Langenscheidt. ISBN 3-468-49660-5

Munadi Yudhi, 2008. Media Pembelajaran. Sebuah Pendekatan Baru. Jakarta: Gaung Persada Press. ISBN : 978-979-1488-49-5 PC Bibliothek Langenscheidt

Sadirman, A, Rahardjo R.,dkk. 2009. Media Pendidikan Pengertian, Pengembangan, dan Pemanfaatannya. Seri Pustaka Teknologi Pendidikan Nomor 6. Jakarta: Rajawali Pers. ISBN 97

Supriyono Agus, 2009. Cooperative Learning : Teori dan Aplikasi PIKEM. Jogjakarta: Pustaka Pelajar.

Thobroni Muhamad \& ArifMustofa, 2011. Belajar \& Pembelajaran Pengembangan Wacana dan Praktik Pembelajaran dalam Pembangunan Nasional. Jogjakarta : Ar-Ruzz-Media. ISBN: 978-979-25-4879-2

Uno, Hamzah \& Nurdin Mohamad, 2011. Belajar dengan Pendekatan PAILKEM, Jakarta: PT Bumi Aksara.

Internet

Die 16 Wappen https://www.hanisauland.de/lehrer-innen/lehrer-innentafelbilder/wbt-bundeslaender-und- hauptstaedte-in-deutschland

Das Bundesländerpuzzle http://www.wissen.de/die-deutschen-bundeslaender-imwissenstest

Schwarzwald https://www.google.coid/search?q=fotos+der+Schwarzwald\&riz

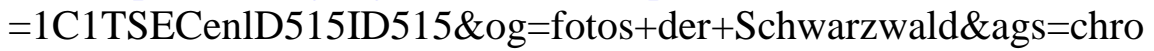
me. 69157.150850198sourceid-chrome\&essm=93\&ie=UTF-8

Sanga F. Analisis Kontrastif Sebagai Sebuah Pendekatan Lado. Ojs.unud.ac.id/index Phplinguistikalarticle/. 1229Translate this page by F Sanga - 2008 - Cited by 1-Related articles, h.7 http://www.ppplkbahasa.net/index.php?opiton-com content\&task=view\&id=15981temid 93

Harz https://www.google.co.id/search?q=fotos+Harz+wald\&riz-1CITSEC enID515ID515\&oq=fotos+Harz+wald\&aqs=chrome.69i57.12002joj $9 \&$ sourceid $=$ chrome \&es $\mathrm{sm}=93 \& \mathrm{ie}=\mathrm{UTF}-8$

Naturpark Teutoburger Wald https://www.google.co.id /search?g=fotos+ Teutoburger+Wald.\&rlz=1CITSECenID5151ID515\&og=fotos+Teut oburger + Wald.\&aqs $=$ chrome.69isz.6545iojo\&sourceid=chrome\&es sm=D93\&ie-UTF-8 
48 Tahuri, Volume 18, Number 2, August 2021

Zadeh Mohamadreza. www.kommunikationkmb.de/./Sektion Kommunikation von Innovationen Summary 080208.pdf - Similar 